\section{Komprimert diagnostisk guide om vertigo}

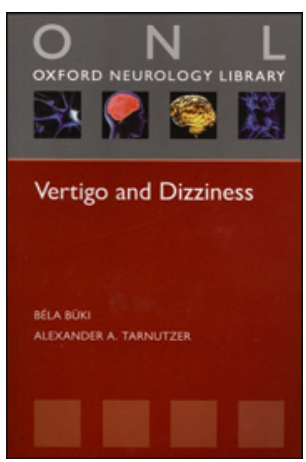

Béla Büki, Alexander A. Tarnutzer Vertigo and dizziness

145 s, tab, ill. Oxford: Oxford University

Press, 2013. Pris GBP 20

ISBN 978-0-19-968062-7

De seneste 20 årene har det foregått en stille revolusjon innen vertigofeltet. Det er nå mulig å skille mellom akutt perifer og sentral vertigo med høy sensitivitet kun ved hjelp av enkle diagnostiske tester. Det har også tilkommet nye diagnoser som dehiscens av den øvre buegangen og kroniske former av krystallsyke (BPPV). Forfatterne går grundig og kortfattet gjennom samtlige nye diagnostiske tester, og alle nye diagnoser tas opp.

En av forfatterne er øre-nese-hals-lege, mens den andre er nevrolog. Både på språket og sammensetningen merker man at de har samarbeidet godt for å dekke hverandres felt. Dette ser man spesielt godt når forfatterne diskuterer vanskelighetene med å skille mellom vestibularisnevritt og PICA/AICA-infarkt. Det faktum at boken er forfattet av en nevrolog og en øre-nese-hals-lege bidrar også til at kjent gammel kunnskap sammenfattes på en bra og lettlest måte.

Når forfatterne tar opp forskjellige behandlinger til perifere årsaker til vertigo, er det dessverre altfor kortfattet. De nevner bare to behandlingsmanøvre innen BPPV-området. De omtaler heller ikke en eneste peroral behandling ved Ménières sykdom. Det er vanskelig for undertegnede å vurdere behandlingskapitlene til de sentrale formene av vertigo, men her ser det ut til å være mer utfyllende skrevet.

Jeg kan sterkt anbefale denne boken til alle kolleger som møter svimle pasienter i førstelinjen. Det er en god og komprimert guide for å skille mellom perifer, sentral, psykologisk eller kardiologisk vertigo. Jeg kan ikke anbefale den like sterkt til leger og andre yrkesgrupper som behandler de forskjellige formene av perifer vertigo, $\mathrm{i}$ og med at behandlingsdelene er noe tynne.

Karl F. Nordfalk

Overlege, Øre-nese-hals-avdelingen

Oslo universitetssykehus, Rikshospitalet

\section{Humanistisk om å arbeide med seksuelle overgripere}

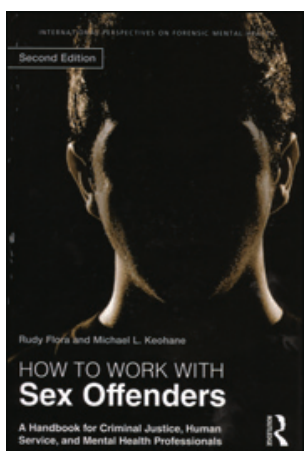

\author{
Rudy Flora, Michael L. Keohane \\ How to work with sex offenders \\ A handbook for criminal justice, human \\ service, and mental health professionals. \\ 2. utg. 290 s, tab. Hove: Routledge, 2013. \\ Pris GBP 35
}

ISBN 978-0-415-52335-6

Fordommer mot i det hele tatt å forholde seg til personer som har begått seksuelle overgrep, er svært utbredt. Det er derfor positivt å lese en bok hvor man nettopp påpeker dette, og hvor man understreker viktigheten av kunnskap. Målgruppen er nok mer det amerikanske samfunnet, som virkelig trenger en bok av dette formatet.

Boken er detaljert og pragmatisk og et viktig bidrag til alle som arbeider klinisk med personer som har begått seksuelle overgrep. Den er et bidrag til et paradigmeskifte $\mathrm{i}$ forståelsen av personer som har begått seksuelle overgrep, over i et humanistisk menneskesyn, selv om handlingene kan være avskyelige. Forfatterne, som begge er kliniske sosionomer, viser store kunnskaper innen feltet - både juridisk og klinisk. Et viktig aspekt er at de ser på overgriperen som pasient.

Forfatterne beskriver juridiske sider, hva som skjer i domstolene, kliniske undersøkelser, ulike typer overgrep og til slutt ulike behandlingsformer fra «sex-addiction»-forståelse til individual-, familieog gruppeterapi. Men de tar også opp ofrene og deres familie.

I mange år har jeg kjempet en kamp mot å kalle barn og unge seksuelle overgripere, og i stedet kalle dem for barn og unge i seksuelle kriser. I USA er det uttrykket «juvenile sex offenders» som brukes. Forfatterne er av samme oppfatning og foreslår «sexual misconduct behavior».

Det blir lite plass til teoretisk og politisk diskusjon. Men for dem som vil vite mer om personer som begår seksuelle overgrep, er dette en viktig bok - også for dem som ikke tilhører den amerikanske kulturen.

En viktig mangel er at forfatterne ikke tar med den nyere tilknytningsforskningen og dens relasjon til overgrepsproblematikk. Flere artikler som direkte knytter tilknytningsskader i tidlig barndom til det senere å begå overgrep, er spennende og kan gi oss ny informasjon om hvordan vi kan forebygge seksuelle overgrep.

At forfatterne i siste utgave refererer til «standards of care» for behandling av både ungdom og voksne, som jeg har vært med på å utforme, er viktig og betryggende $(1,2)$. Det plasserer boken i en humanistisk diskurs som det er viktig å kjempe for.

Thore Langfeldt

Psykolog, Institutt for klinisk sexologi og terapi Oslo

Litteratur

1. Coleman E, Dwyer SM, Abel G et al. Standards of care for the treatment of adult sex offenders. J Psychol Human Sex 2000: 11: 11-7.

2. Miner M, Borduin C, Prescott $D$ et al. Standards of care for juvenile sexual offenders of the international association for the treatment of sexual offenders. Sexual Offender Treatment 2006; 1. 